\title{
22. NEOGENE SILICOFLAGELLATES FROM DEEP SEA DRILLING PROJECT SITE 543, WESTERN TROPICAL ATLANTIC OCEAN ${ }^{1}$
}

\author{
David Bukry, United States Geological Survey, Scripps Institution of Oceanography²
}

\begin{abstract}
The upper lower Miocene silicoflagellate assemblage in Core 19 from DSDP Hole 543 in the western Atlantic Ocean contains the greatest concentration $(41 \%)$ of deflandroid Dictyocha pulchella yet observed. The deflandroid morphology in Dictyocha persisted through the Eocene and Oligocene at middle and high latitude, but virtually disappeared in the late Oligocene, only to reappear as a short-lived variant of $D$. pulchella near the end of the early Miocene or the beginning of the middle Miocene at several low-latitude sites. Correlations with coeval tropical silicoflagellate and diatom assemblages from the tropical eastern Pacific and eastern Atlantic suggest that this deflandroid morphotype may be stratigraphically useful. A new diatom, Craspedodiscus barronii Bukry, found in Core 543-19, is described.
\end{abstract}

\section{SILICOFLAGELLATE CORRELATION AND DIATOM EVIDENCE}

Investigation of Miocene biosiliceous radiolarian sediment from Hole $543\left(15^{\circ} 42.726^{\prime} \mathrm{N}, 58^{\circ} 39.243^{\prime} \mathrm{W}\right.$, water depth $5633 \mathrm{~m}$ ) showed that most samples are barren of silicoflagellates. Of 19 samples examined from Cores 17 to 32 (161-313 m sub-bottom), only three contain silicoflagellates and none contain coccoliths. The silicoflagellates are characteristic of the lower and middle Miocene Corbisema triacantha Zone (Bukry, 1981), and occur only in Cores 18 and 19. These cores are assigned to the upper lower Miocene Calocycletta costata Zone of radiolarians (Renz, this volume). The associated diatom assemblage with Actinocyclus ehrenbergii, Annellus californicus, Coscinodiscus lewisianus, Craspedodiscus coscinodiscus, Rossiella paleacea, Triceratium cinnamomeum var. minor, and Denticulopsis nicobarica, without Actinocyclus ingens, is also assigned to the upper lower Miocene (John A. Barron, personal communication, 1981).

The silicoflagellates (Table 1) are distinguished by the abundant occurrence of deflandroid specimens of Dictyocha pulchella. The deflandroid morphology (Plate 1, Figs. 7-11) - apical bar modified into a plate-has previously been noted in specimens from coeval samples from DSDP Holes 369A, 370, 391A, 415, and 416A, all in the tropical North Atlantic Ocean (Bukry, 1978a, $1978 \mathrm{~b}, 1980)$. Maximum abundances are only $5 \%$ to $9 \%$, instead of the high $41 \%$ for Hole 543 . The specimens from Hole 543 are unique in the flattening of the struts and the ring apices on many specimens, in addition to the usual central bar flattening. The presence of deflandroid $D$. pulchella with Corbisema triacantha and Mesocena elliptica, in the absence of Naviculopsis and Dictyocha brevispina ausonia or D. pons, suggests that the Hole 543 population is older than the populations sampled from Holes $416 \mathrm{~A}$ and 415 , off northwest

\footnotetext{
${ }^{1}$ Biju-Duval, B., Moore, J. C., et al., Init. Repts. DSDP, 78A: Washington (U.S. Govt. Printing Office)

Address: U.S. Geological Survey, Scripps Institution of Oceanography, La Jolla, CA
}

Table 1. Silicoflagellate percentages in upper lower Miocene samples from Hole 543, Cores 18 and 19.

\begin{tabular}{|c|c|c|c|}
\hline & \multicolumn{3}{|c|}{ Sample ${ }^{a}$} \\
\hline & $\begin{array}{c}18-6, \\
40-41 \\
(178)\end{array}$ & $\begin{array}{c}19-1, \\
23-24 \\
(180)\end{array}$ & $\begin{array}{c}19-2, \\
23-24 \\
(182)\end{array}$ \\
\hline Corbisema triacantha & & & 2 \\
\hline Dictyocha sp. cf. D. brevispina ausonia & & & $<1$ \\
\hline D. fibula s. ampl. & & & 1 \\
\hline D. pulchella & $\mathrm{X}$ & $\mathbf{X}$ & 34 \\
\hline D. pulchella [deflandroid] & & & 41 \\
\hline D. pulchella [deflandroid, flat rim] & & & 1 \\
\hline Distephanus crux parvus & & $\mathrm{x}$ & $*$ \\
\hline D. speculum patulus & & & 1 \\
\hline D. speculum speculum & & & 2 \\
\hline Macrora stella & & & $<1$ \\
\hline Mesocena elliptica & & & 17 \\
\hline Total specimens & 4 & 2 & 300 \\
\hline
\end{tabular}

Note: $\mathrm{X}=$ present but too sparse for percentages. ${ }^{*}=$ recorded after count completed.

a Sub-bottom depth in meters (within parentheses).

Africa, which contain lower middle Miocene (coccolith Zone CN4) deflandroid D. pulchella. The lack of diatom Actinocyclus ingens and the presence of the older square-profiled form of var. californicus (see Barron, 1981) also support a greater age and an assignment to the upper lower Miocene for the Hole 543 samples. The diatoms are correlative with the tropical assemblages recovered in Cores 25 to 27 from DSDP Hole 77B in the equatorial Pacific.

Lower Miocene/middle Miocene boundary assemblages of silicoflagellates have been cored six times in the southern Indo-Pacific at Sites 206, 266, 274, 278, and 323, and at northeastern Pacific Site 495, but deflandroid Dictyocha pulchella has been recorded only at Site 495, off Guatemala. This indicates an ecologically limited Atlantic and easternmost Pacific distribution for this morphotype, or removal of this stratigraphic level by hiatus in the Indo-Pacific (see NH2 of Keller and Barron, 1983). Hiatus NH2 is described by Keller and 
Barron to be associated with tectonic constriction of flow between the Atlantic and Pacific oceans in the Central American region. This effect could contribute to the known Atlantic and easternmost Pacific distribution pattern of deflandroid Dictyocha pulchella.

Although only one silicoflagellate-rich level from the upper lower Miocene is available for study at Site 543 (and it is speculative to generalize from a single sample), several stratigraphic and ecologic relations can be explored through this assemblage. Biostratigraphically, the lack of cosmopolitan Actinocyclus ingens and Naviculopsis indicates a brief interval of deposition just below the lower Miocene/middle Miocene boundary. But the species array of the assemblage is unusual because of the combined paucity of Corbisema triacantha and Distephanus crux s. ampl., and the absence of Mesocena apiculata curvata, which can be rather common in upper lower Miocene assemblages. The common Mesocena elliptica helps to suggest a level of comparison to other assemblages. For example, DSDP Core 370-3 contains Corbisema triacantha, Dictyocha pulchella [deflandroid], and $M$. elliptica, but is predominated by Distephanus crux, which is considered to be favored in waters of temperate coastal influence (Bukry and Foster, 1973). Although the genus Corbisema is considered to have favored warmer waters than Distephanus, the DSDP sites having maximum abundances of the terminal species, Corbisema triacantha, in the C. triacantha Zone are also temperate coastal locations, such as Sites 415 and 470 . Lower-latitude DSDP Sites 158 and 495 and open-ocean DSDP Site 66 have less abundant $C$. triacantha. Therefore, the high paleotemperature value $(T S)$ - based on relative abundances of warm and temperate genera (Bukry, 1983) - of 91 for Site 543 and the paucity of those higher-latitude taxa are appropriate to its more tropical and oceanic location to the northnortheast of Barbados.

Site 495, in the eastern Pacific off Guatemala, is located at lat $12^{\circ} \mathrm{N}$, slightly farther south than Site 543 at lat $16^{\circ} \mathrm{N}$. Upper lower Miocene strata of Core 495-26 have been assigned to the Calocycletta costata Zone of radiolarians and the Helicosphaera ampliaperta Zone of coccoliths. The silicoflagellates studied from there are remarkably similar to those in coeval samples from Hole 543, with Dictyocha pulchella, D. pulchella (deflandroid), and Mesocena elliptica as the dominant species (Table 2). No Corbisema triacantha was found at Site 495, but relative paleotemperature values of $T s=$ 80 for Section 495-26-1 and $T s=95$ for Section 495-26-3 support the tropical high value of $T s=91$ for Site 543 . The only obvious difference between the assemblages is that the one from Site 543 has a greater number of deflandroid $D$. pulchella with the plate elongate parallel to the major axis. Among the diatoms, the main difference at Site $\mathbf{4 9 5}$ is the absence of Craspedodiscus barronii and Denticulopsis nicobarica. A lack of Craspedodiscus and Denticulopsis, coupled with the relatively fewer deflandroid $D$. pulchella at Site 495 , suggests it was in a somewhat warmer regime than Site 543 (J. A. Barron, oral communication, 1982).
Table 2. Silicoflagellate percentages in upper lower Miocene samples from Hole 495, Core 26.

\begin{tabular}{|c|c|c|}
\hline & \multicolumn{2}{|c|}{ Sample ${ }^{a}$} \\
\hline & $\begin{array}{c}26-1, \\
75-79 \\
(248)\end{array}$ & $\begin{array}{c}26-3, \\
75-79 \\
(251)\end{array}$ \\
\hline Dictyocha sp. cf. D. brevispina ausonia & 2 & 2 \\
\hline D. fibula s. ampl. & $<1$ & 2 \\
\hline D. pulchella & 46 & 55 \\
\hline D. pulchella [deflandroid] & 13 & 30 \\
\hline Distephanus speculum haliomma & $<1$ & \\
\hline Mesocena elliptica & 38 & 12 \\
\hline Total specimens & 300 & 60 \\
\hline
\end{tabular}

a Sub-bottom depth in meters (within parentheses).

Synonymies and discussions for silicoflagellate taxa are available in my previous DSDP publications for Legs 16 to 68. Macrora is an extinct genus of uncertain affinities which is treated as a silicoflagellate (Bukry, 1978 c). See Barron $(1980,1981)$ for diatom synonymies and discussions. Some representative silicoflagellates and diatoms from Hole 543 are shown in Plates 1-3. Below is a summary list of the taxa cited.

\section{SPECIES CONSIDERED}

\section{Silicoflagellates}

Corbisema triacantha (Ehrenberg) Hanna

Dictyocha brevispina ausonia (Deflandre) Bukry

D. fibula Ehrenberg

D. pons Ehrenberg

D. pulchella Bukry

Distephanus crux parvus (Bachmann) emended Bukry

D. speculum patulus Bukry

D. speculum speculum (Ehrenberg) Haeckel

Macrora stella (Azpeitia) Hanna

Mesocena apiculata curvata Bukry

Mesocena elliptica (Ehrenberg) Ehrenberg

Diatoms

Actinocyclus cubitus Hanna et Grant

A. ehrenbergii Ralfs

$A$. ingens Rattray

Annellus californicus var. californicus Tempere

Cestodiscus pulchellus Greville

Coscinodiscus lewisianus Greville

Craspedodiscus coscinodiscus Ehrenberg

Denticulopsis nicobarica (Grunow) Simonsen

Rossiella paleacea (Grunow) Desikachary et Maheshwari

Triceratium cinnamomeum var. minor Grunow

\section{NEW DIATOM TAXONOMY}

\section{Genus CRASPEDODISCUS Ehrenberg, 1845}

Craspedodiscus barronii Bukry, n. sp.

(Plate 2, Figs. 13-15; Plate 3, Figs. 1-5)

Craspedodiscus coscinodiscus Ehrenberg, Bukry, 1980 (in part), p. 520 , pl. 5, fig. 1 (not fig. 2).

Description. Craspedodiscus barronii is large and circular with a moderate-sized, shallow, circular depression that occupies a half or slightly less of the valve diameter. Hexagonal areolae are arranged in radial rows; from a small solid center, the areolae enlarge gradually up the sides of the central depression and are largest $(3-5 \mu \mathrm{m})$ for a sequence of five areolae just outside the upper edge of the depression. At the margin, one or two smaller areolae end the radial lines. The valve surface slopes slightly away from the central depression and 
steepens at the margin. The transition from central depression to peripheral valve surface is not marked by any demarcation line.

Remarks. Craspedodiscus barronii is distinguished from Craspedodiscus cascinodiscus by regular radial lines of areolae from center point to margin, by secondary spiral, and by the absence of a sharp demarcation boundary between central and peripheral areas. Specimens of the population studied are broken.

Occurrence. Craspedodiscus barronii is known from the upper lower Miocene Corbisema triacantha Zone of Sample 543-19-2, 23-24 $\mathrm{cm}$ (182 m sub-bottom), recovered in the western tropical Atlantic, north-northeast of Barbados, and Sample 415-5-2, 58-60 cm (276 m sub-bottom), taken in the eastern Atlantic off Morocco.

Size. Maximum diameters, rim $145 \mu \mathrm{m}$, central depression $70 \mu \mathrm{m}$.

Holotype. USNM 339713 (Plate 3, Fig. 2).

Isotypes. USNM 339714 to 339719.

Type locality. Western tropical Atlantic Ocean, DSDP Sample 543-19-2, 23-24 cm (182 m sub-bottom).

\section{ACKNOWLEDGMENTS}

I thank Nona Renz Killmar, DSDP, for suggesting study of Hole 543 Cores 18 and 19 as the most likely source for silicoflagellates from Leg 78A. John Barron, U.S. Geological Survey, generously provided state-of-the-art information on questions about Miocene diatoms. I also thank Gerta Keller and Jack Baldauf, U.S. Geological Survey, for their constructive manuscript review, and Dorothy Blackstock, U.S. Geological Survey, for typing and proofing the paper.

\section{REFERENCES}

Barron, J. A., 1980. Lower Miocene to Quaternary diatom biostratigraphy of Leg 57, off northeastern Japan, Deep Sea Drilling Project. In Scientific Party Init. Repts. DSDP, 56, 57, Pt. 2: Washington (U.S. Govt. Printing Office), 641-685.

1981. Late Cenozoic diatom biostratigraphy and paleoceanography of the middle-latitude eastern North Pacific, Deep Sea Drilling Project Leg 63. In Yeats, R. S., Haq, B. U., et al., In- it. Repts. DSDP, 63: Washington (U.S. Govt. Printing Office), 507-538.

Bukry, D., 1978a. Cenozoic coccolith and silicoflagellate stratigraphy, offshore northwest Africa, Deep Sea Drilling Project Leg 41. In Lancelot, Y., Seibold, E., et al., Init. Repts. DSDP, 41: Washington (U.S. Govt. Printing Office), 689-707.

1978b. Cenozoic coccolith, silicoflagellate, and diatom stratigraphy, Deep Sea Drilling Project Leg 44. In Benson, W. E., Sheridan, R. E., et al., Init. Repts. DSDP, 44: Washington (U.S. Govt. Printing Office), 807-863.

1978c. Cenozoic silicoflagellate and coccolith stratigraphy, northwestern Atlantic Ocean, Deep Sea Drilling Project Leg 43: In Benson, W. E., Sheridan, R. E., et al., Init. Repts. DSDP, 44: Washington U.S. Govt. Printing Office), 775-805.

1980. Miocene Corbisema triacantha Zone phytoplankton from Deep Sea Drilling Project Sites 415 and 416, off northwest Africa. In Lancelot, Y., Winterer, E. L., et al., Init. Repts. DSDP, 50: Washington (U.S. Govt. Printing Office), 507-523.

1981. Synthesis of silicoflagellate stratigraphy for Maestrichtian to Quaternary marine sediment. Soc. Econ. Paleontol. Mineral. Spec. Publ., 32:433-444.

1983. Upper Cenozoic silicoflagellates from offshore Ecuador, Deep Sea Drilling Project Site 504. In Cann, J. R., Langseth, M. G., Honnorez, J., Von Herzen, R. P., White, S. M. et al., Init. Repts. DSDP, 69: Washington (U.S. Govt. Printing Office), 321-342.

Bukry, D., and Foster, J. H., 1973. Silicoflagellate and diatom stratigraphy, Leg 16, Deep Sea Drilling Project. In van Andel, Tj. H., Heath, G. R., et al., Init. Repts. DSDP, 16: Washington (U.S. Govt. Printing Office), 815-871.

Keller, G., and Barron, J. A., 1983. Paleoceanographic implications of Miocene deep sea hiatuses. Geol. Soc. Am. Bull., 94:590-613.

Date of Initial Receipt: July 6, 1982

Date of Acceptance: August 6, 1982 


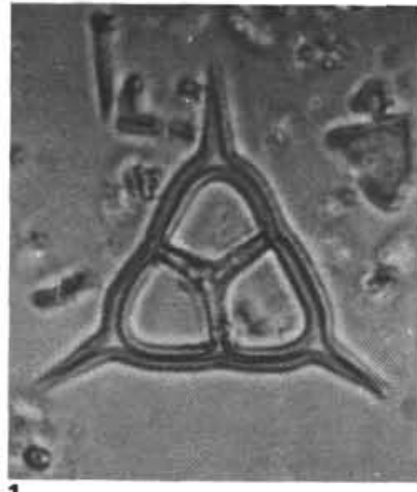

1

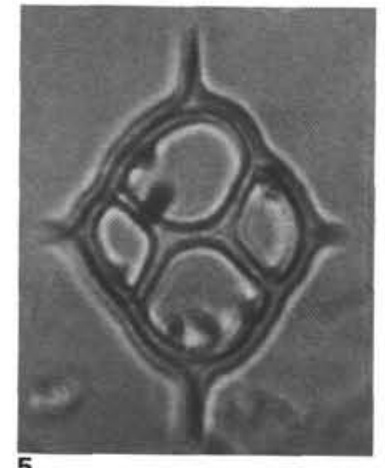

5

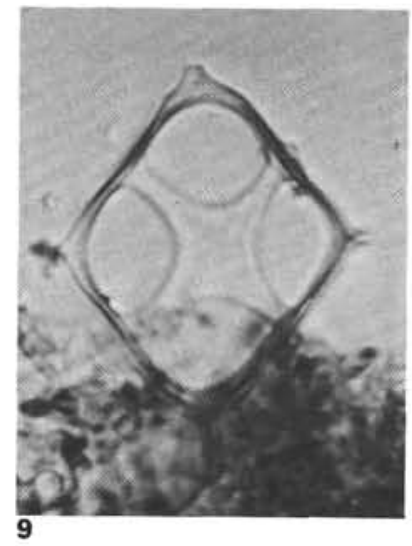

6

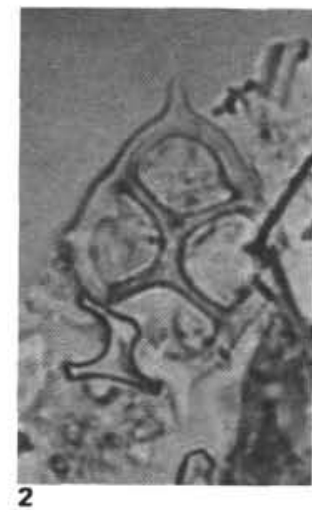

2
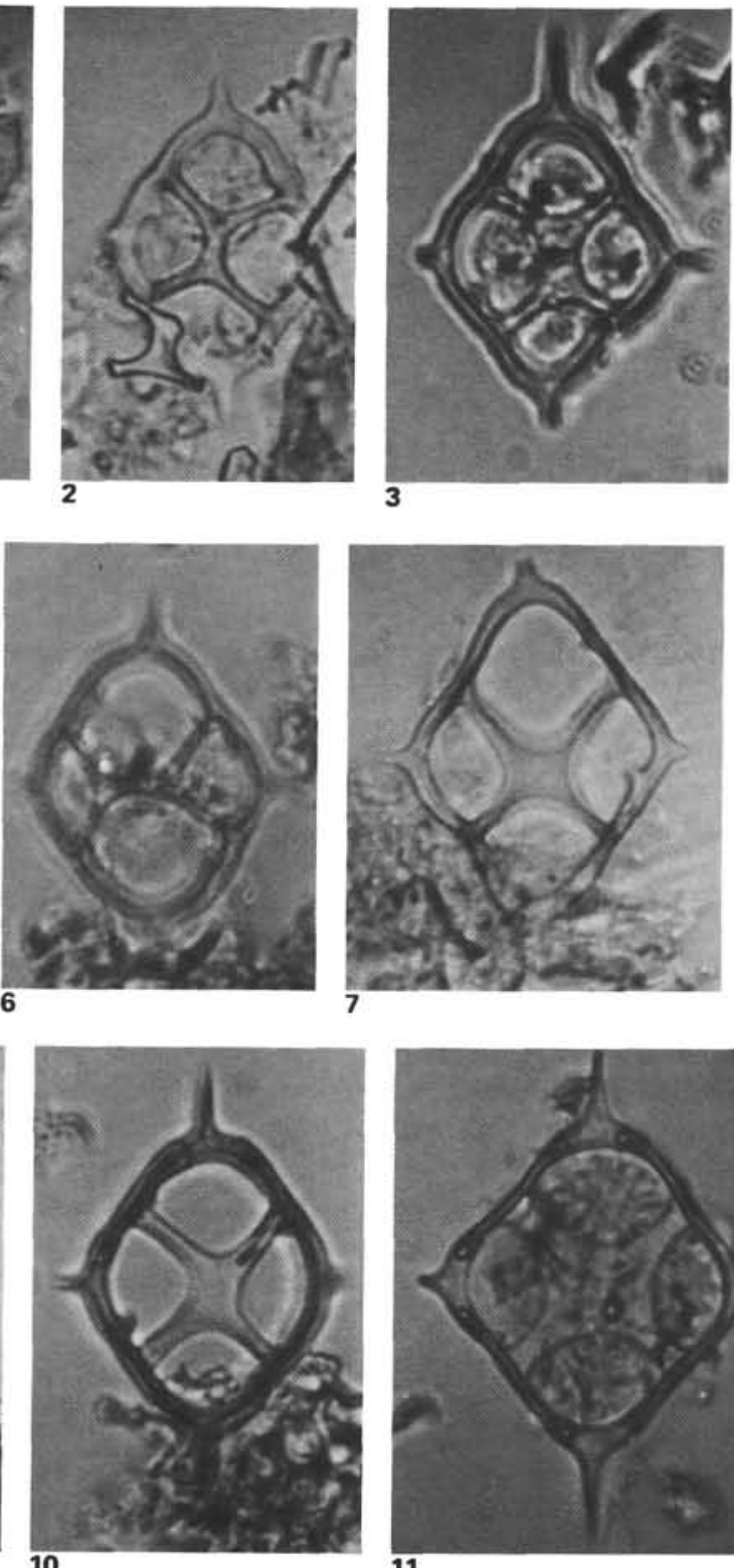
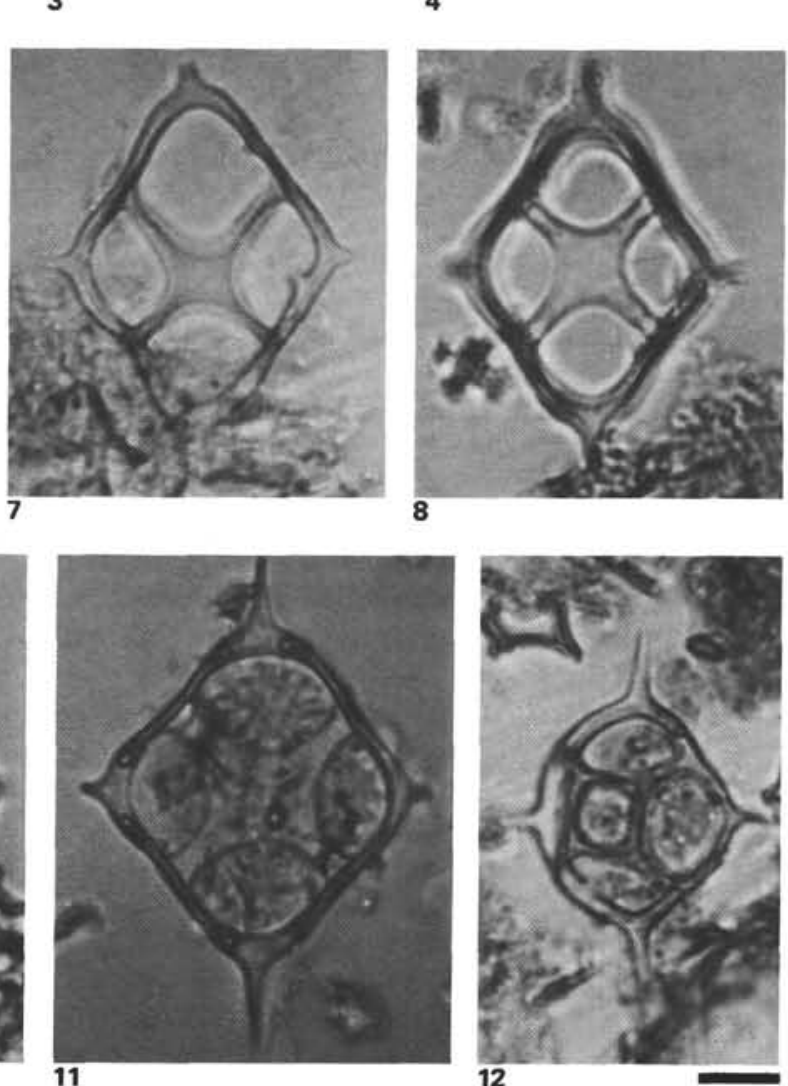

Plate 1. Miocene silicoflagellates from DSDP Hole 543. (All figures are magnified $850 \times$; scale bar $=10 \mu \mathrm{m}$. All specimens are from Sample 54319-2, 23-24 cm, except Fig. 12, which is from Sample 543-19-1, 23-24 cm.) 1. Corbisema triacantha (Ehrenberg). 2. Dictyocha fibula Ehrenberg. 3. Dictyocha fibula Ehrenberg (deflandroid). 4-6. Dictyocha pulchella Bukry. 7-11. Dictyocha pulchella Bukry (deflandroid). 12. Distephanus crux parvus (Bachmann) emended Bukry, 1983. 


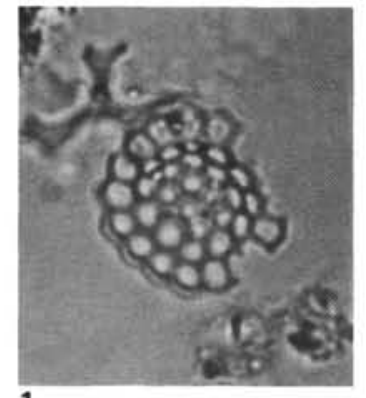

1

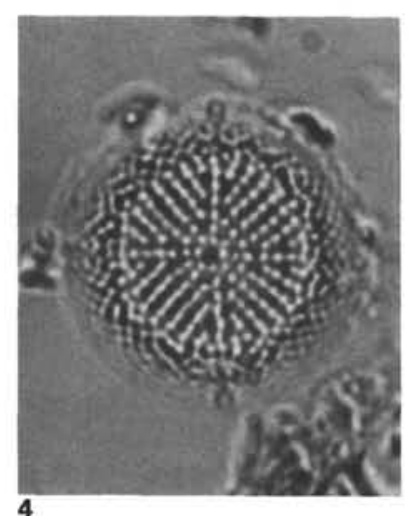

4
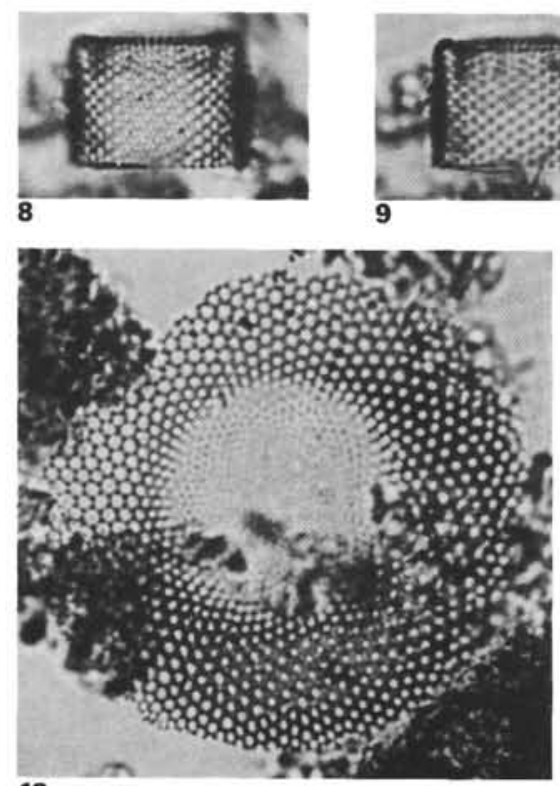

13

5
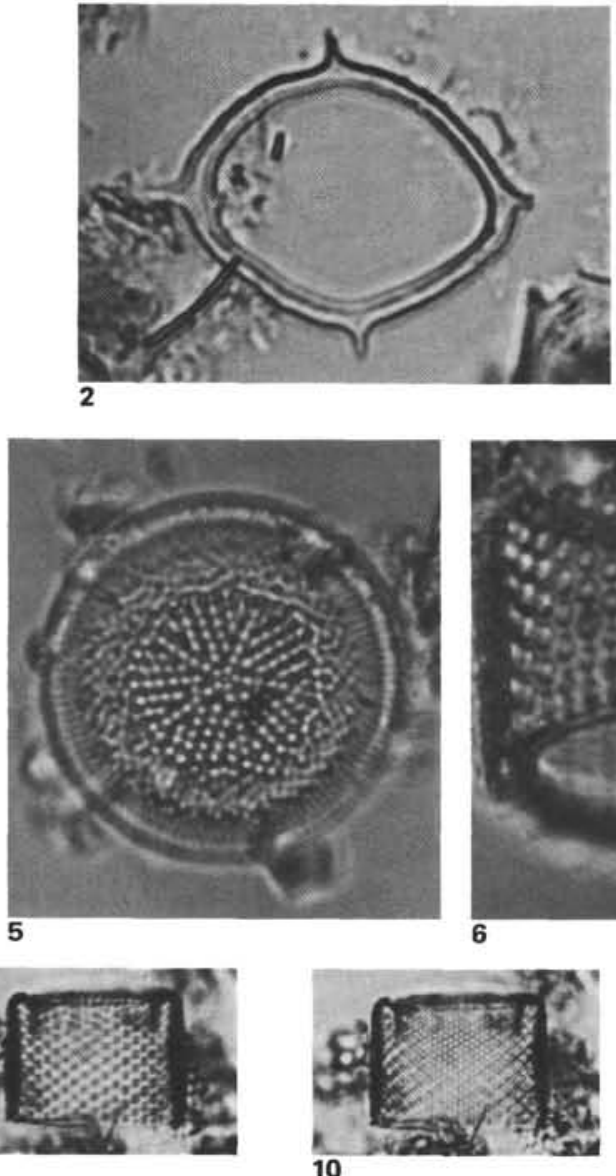

10
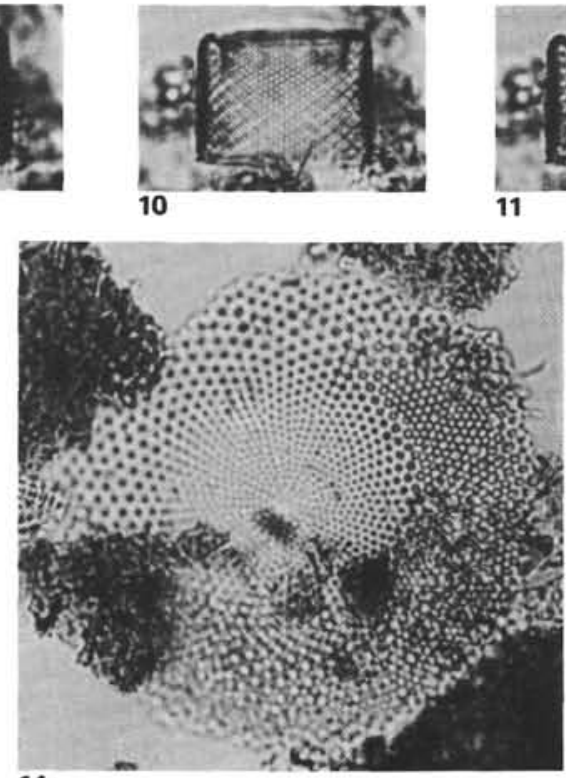

14

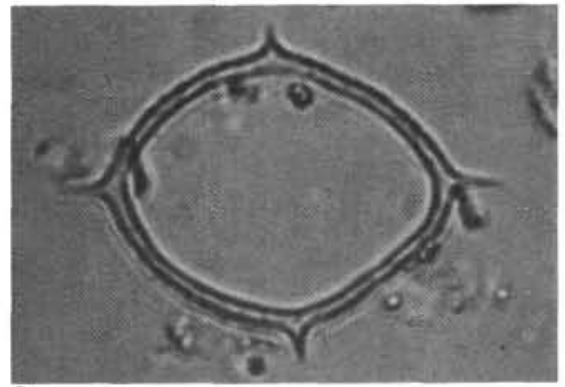

3
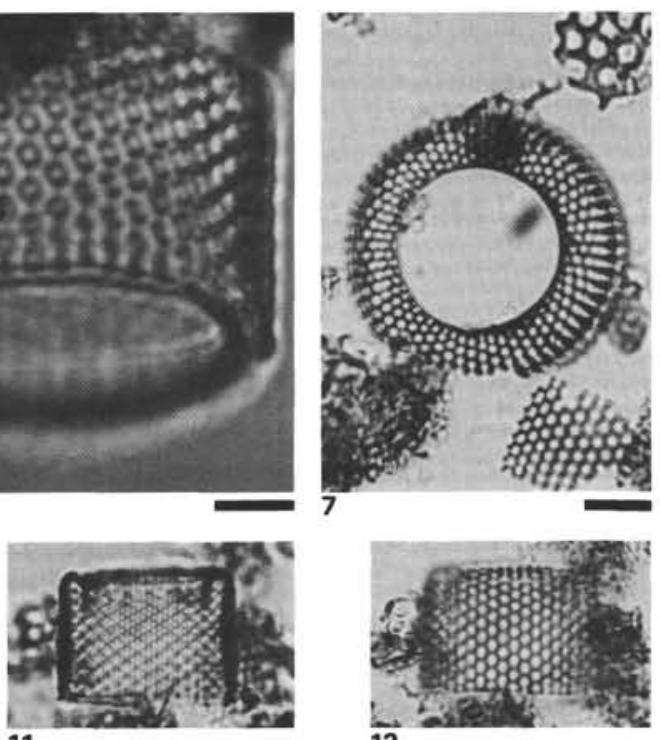

11
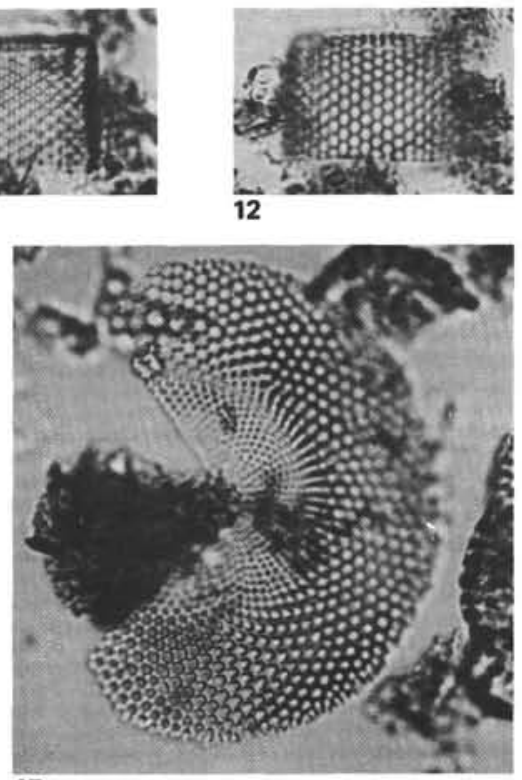

15

Plate 2. Miocene silicoflagellates and diatoms from DSDP Hole 543. (Figs. 1-6 are magnified $850 \times$; scale bar $=10 \mu \mathrm{m}$. Figs. 7-15 are magnified $350 \times$; scale bar $=20 \mu \mathrm{m}$. Figs. $1-5$ and 13-15 are from Sample 543-19-2, 23-24 cm. Figs. 6-12 are from Sample 543-18-6, 40-41 cm.) 1. Macrora stella (Azpeitia). 2,3. Mesocena elliptica (Ehrenberg). 4,5. Actinocyclus cubitus Hanna et Grant. 6-12. Annellus californicus var. californicus Tempere. (8-12) Through-focal series of same specimen. 13-15. Craspedodiscus barronii Bukry, n. sp. (13, 14) USNM 339714, high and low focus, (15) USNM 339715. 

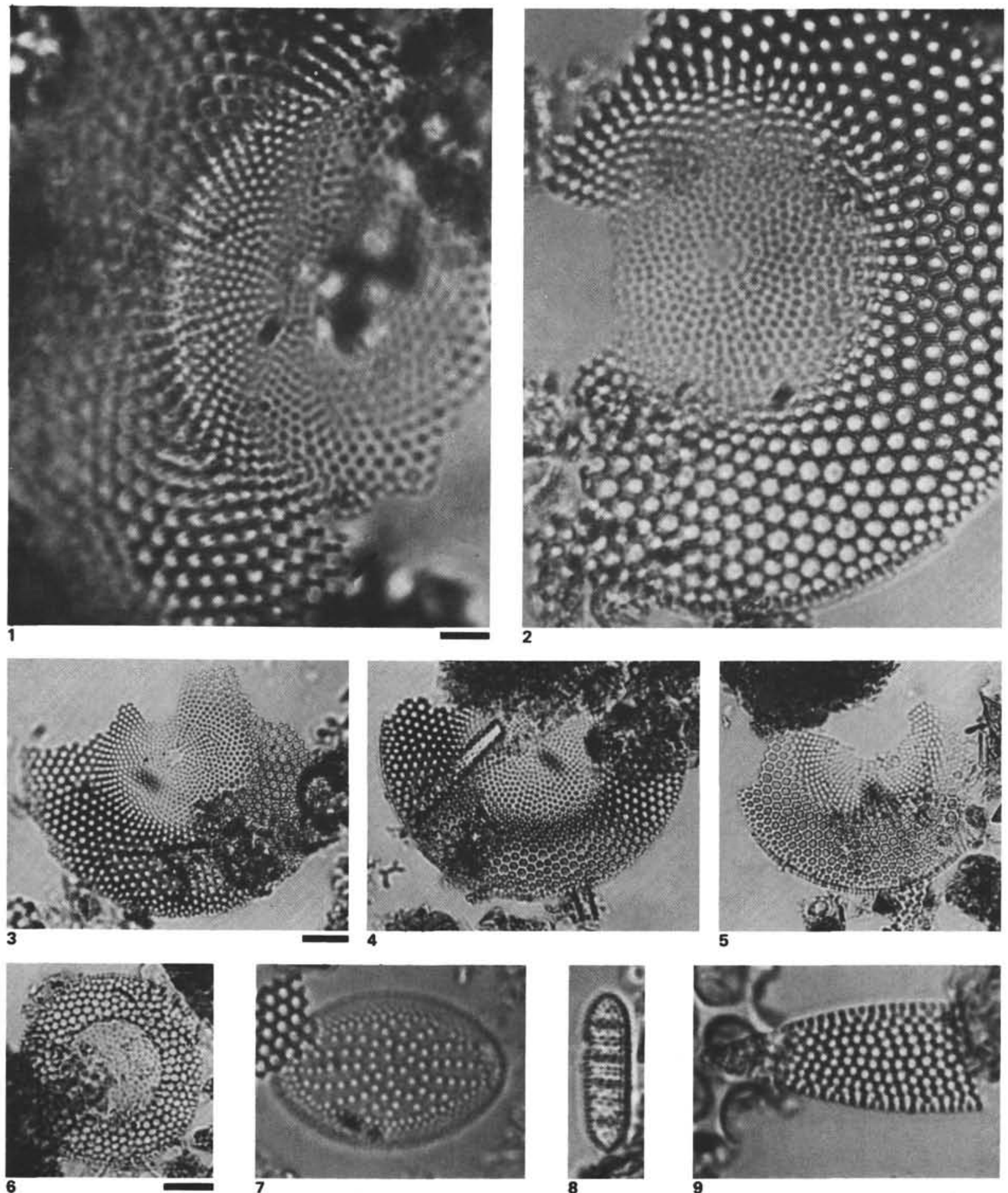

Plate 3. Miocene diatoms from DSDP Hole 543. (Figs. 1, 2, 7-9 are magnified $850 \times$; scale bar $=10 \mu \mathrm{m}$. Figs. 3-5 are magnified 350 $\times$; scale bar $=20 \mu \mathrm{m}$. Fig. 6 is magnified $400 \times$; scale bar $=20 \mu \mathrm{m}$. All specimens are from Sample 543-19-2, 23-24 cm.) 1-5. Craspedodiscus barronii Bukry, n. sp. (1) USNM 339716, (2) Holotype, USNM 339713, (3) USNM 339717, (4) USNM 339718, (5) USNM 339719. 6. Craspedodiscus coscinodiscus Ehrenberg. 7. Coscinodiscus lewisianus Greville. 8. Denticulopsis nicobarica (Grunow). 9. Rossiella paleacea (Grunow). 